\title{
Etiologies of sperm DNA damage and its impact on male infertility
}

\author{
Manesh Kumar Panner Selvam ${ }^{1}$ (D) | Rafael F. Ambar ${ }^{1,2}$ (D) | Ashok Agarwal ${ }^{1}$ (D) | \\ Ralf Henkel ${ }^{1,3}$ (D)
}

\author{
${ }^{1}$ American Center for Reproductive \\ Medicine, Cleveland Clinic, Cleveland, $\mathrm{OH}$, \\ USA \\ ${ }^{2}$ Sexual and Reproductive Medicine - \\ Department of Urology, Faculdade de \\ Medicina do ABC, Santo André, Brazil \\ ${ }^{3}$ Department of Medical Bioscience, \\ University of the Western Cape, Bellville, \\ South Africa \\ Correspondence \\ Ashok Agarwal, American Center for \\ Reproductive Medicine, Cleveland Clinic, \\ Mail Code X-11, 10681 Carnegie Avenue, \\ Cleveland, $\mathrm{OH} 44195$, USA. \\ Email: agarwaa@ccf.org; \\ www.Clevelandclinic.org/ \\ ReproductiveResearchCenter
}

\begin{abstract}
Male factor is responsible for up to $50 \%$ of infertility cases in the world. Semen analysis is considered the cornerstone of laboratory evaluation of male infertility, but it has its own drawbacks and fails to predict the male fertility potential with high sensitivity and specificity. Different etiologies have been linked with male infertility, of which sperm DNA damage has gained significant attention with extensive research on sperm function tests. The associations between sperm DNA damage and a variety of disorders such as varicocele, obesity, cancer, radiation and lifestyle factors are explored in this review. Furthermore, we discuss the mechanisms of DNA damage as well as its impact in different scenarios of male infertility, associated with spontaneous and assisted reproduction. Finally, we review the clinical applicability of sperm DNA fragmentation testing in the management of male infertility.
\end{abstract}

\section{KEYWORDS}

assisted reproduction technology, fertilization failure, male infertility, sperm DNA damage

\section{1 | BACKGROUND}

Infertility is defined as the inability to conceive after 12 months of regular, unprotected intercourse (Sabanegh \& Agarwal, 2010). Although $60 \%-75 \%$ of couples conceive within 6 months, and $90 \%$ within 12 months (Spira, 1986), approximately 48.5 million couples worldwide are considered infertile within this definition (Agarwal et al., 2019; Sharlip et al., 2002). Male factor infertility affects up to $50 \%$ of couple infertility and is solely responsible for $20 \%$ of overall infertility (Thonneau et al., 1991). In recent decades, the incidence of male factor infertility has increased (Turner et al., 2020; Zandieh et al., 2018).

Semen analysis is considered as the cornerstone of the male fertility evaluation. This analysis provides information into the possible extent and severity of infertility problems, and aids in diagnosis and clinical management. Based on several population studies, the World Health Organization (WHO) provided updated sampling and laboratory guidelines with clinical thresholds to evaluate male reproductive potential through semen analysis (Mayorga-Torres, Camargo, Cadavid, du Plessis, \& Cardona Maya, 2017). However, there remain several limitations associated with the conventional semen analysis in the assessment of male infertility (Majzoub, Agarwal, \& Esteves, 2019). These limitations have led to the development of advanced sperm function and seminal fluid quality assessments, such as oxidative stress and sperm DNA fragmentation (SDF), that may better guide diagnostics, management and the prediction of male fertility outcomes (Esteves, Sharma, Gosálvez, \& Agarwal, 2014).

Spermatozoa are highly differentiated cells, which are made up of a head, mid piece and tail. The head of the spermatozoa contains the haploid genome that is transmitted into the oocyte after successful fertilization. The integrity and composition of the sperm DNA is different from that of somatic cells and critical for its fusion with the maternal genome (Conwell, Vilfan, \& Hud, 2003). Adequate sperm DNA integrity is critical for successful fertilization, embryo development, implantation and establishment of pregnancy as it contributes towards 50\% of the embryonic genome (Baskaran et al., 2019; Braude, Bolton, \& Moore, 1988). Sperm DNA integrity is therefore considered as an important marker of fertility potential of spermatozoa (Cho \& Agarwal, 2018). 
Due to chromatin condensation in the maturation of spermatozoa, sperm DNA is protected against damage that could occur during its transport through the male and female reproductive tracts (Erenpreiss, Spano, Erenpreisa, Bungum, \& Giwercman, 2006). Sperm DNA damage $>30 \%$ has been associated with delayed pregnancy and considered as better predictor of pregnancy (Santi, Spaggiari, \& Simoni, 2018; Spanò et al., 2000). Based on the site and nature of damage, sperm DNA damage is categorised as (a) DNA fragmentation, (b) mitochondrial DNA damage, (c) telomere attrition, (d) Y-chromosome microdeletions and (e) epigenetic abnormalities (Bui, Sharma, Henkel, \& Agarwal, 2018; Elbardisi et al., 2019). While some degree of damage is inevitable, and spermatozoa do not have the capacity to repair their own DNA, SDF can be repaired by factors present in the oocyte's cytoplasm. However, when the damage exceeds the oocyte's repair capacity, this may result in impaired fertilization and pregnancy failure (Evenson et al., 1999; Henkel et al.,2004). Importantly, increased SDF has been reported in men with abnormal semen parameters (Huang et al., 2005) as well as in normozoospermic partners of an infertile couple (Saleh et al., 2002). Although there are numerous intrinsic and extrinsic risk factors for SDF, common underlying causes include abnormal chromatin condensation, abortive apoptosis and oxidative stress. Due to the increasing importance of SDF in male fertility and reproductive outcomes, this review discusses the causes and mechanisms associated with SDF.

\section{2 | CAUSES OF SPERM DNA DAMAGE}

Both testicular and ejaculated spermatozoa are prone to sperm DNA damage. Damage to testicular spermatozoa can occur during spermatogenesis and maturation. Post-testicular damage may take place during sperm transport through the male reproductive tract. Defective spermatogenesis and abnormalities in chromatin remodelling and abortive apoptosis are the major factors affecting the integrity of sperm DNA through spermatogenesis. Increased testicular and post-testicular oxidative stress induces DNA damage. In general, both nuclear and mitochondrial sperm DNA are damaged due to oxidative stress (Bui et al., 2018).

\section{1 | Mechanisms of SDF}

\subsection{1 | Defective spermatogenesis and chromatin remodelling}

During spermatogenesis, sperm DNA undergoes protamination, a process in which the histones bound to the DNA are replaced with protamines resulting in a decreased histone to protamine ratio. Protamination of sperm DNA, in turn, is essential for the nuclear condensation, and dysregulation of this process in spermatozoa may result in the SDF. However, the degree of sperm DNA breaks and damage may be increased in the spermatozoa of infertile men (Simon et al., 2017). Furthermore, the organization of chromatin during fertilization and embryo development is determined by the integrity of the paternal DNA (Ajduk, Yamauchi, \& Ward, 2006; Simon et al., 2014; Ward, 2010). During spermatogenesis, stages of cell cycle recombination check points remove the spermatocytes with defective DNA. This allows for only the spermatocytes with intact DNA to proceed in the spermatogenesis process (Page \& Orr-Weaver, 1997). The majority of the protamination occurs during epididymal transit to maintain the integrity of the DNA in ejaculated spermatozoa (Erenpreiss, Bars, Lipatnikova, Erenpreiss, \& Zalkalnas, 2001). The presence of DNA breaks in ejaculated spermatozoa is indicative of either defective chromatin remodelling during spermatogenesis or maturation failure.

\subsection{2 | Abortive apoptosis}

Spermatogenesis involves mitotic and meiotic division of germ cells, thereby producing haploid spermatozoa. Sertoli cells provide nutrition to these germ cells (Griswold, 1998), and proper maintenance of Sertoli cell to germ cell ratio is essential for normal proliferation and apoptosis of spermatogonial cells. Most germ cells become defective due to accidental damage or genetic abnormalities at different stages of spermatogenesis (Print \& Loveland, 2000). Apoptotic markers Fas and FasL are expressed by germ cells and Sertoli cells respectively. Furthermore, the Sertoli cells expressing the FasL initiate the apoptosis of germ cells expressing Fas (Lee, Richburg, Younkin, \& Boekelheide, 1997; Rodriguez, Ody, Araki, Garcia, \& Vassalli, 1997), which are subsequently phagocytosed by Sertoli cells. However, some germ cells escape this programmed elimination process and undergo maturation. These are then identified in the ejaculate as defective spermatozoa. This phenomenon is known as abortive apoptosis, and it is reported in infertile men with abnormal sperm parameters (Sakkas, Mariethoz, \& St John, 1999). Due to incomplete apoptosis, these defective germ cells are associated with high levels of DNA damage.

\subsection{Intrinsic risk factors for sperm DNA damage}

DNA damage can occur due to several intrinsic factors, and it may have negative impact on the fertilization process or could lead to assisted reproduction technique (ART) failures. Table 1 provides an overview of all the intrinsic causes of sperm DNA damage. Defects in sperm DNA can arise from the following sources.

\subsection{1 | Varicocele}

Varicocele, characterized by an abnormal tortuosity and dilation of the veins of the pampiniform plexus, is a common condition prevalent in $15 \%$ of the general population, accounting for $25 \%-40 \%$ of primary and $45 \%-81 \%$ of secondary infertility cases (Alsaikhan, Alrabeeah, Delouya, \& Zini, 2016; Shabana et al., 2015). Furthermore, varicocele is the most common surgically correctible 
TABLE 1 Intrinsic causes of sperm DNA damage

\begin{tabular}{|c|c|c|}
\hline Etiology & Studies & Main Findings \\
\hline \multirow[t]{3}{*}{ Varicocele } & Zini et al. (2011), Zini and Dohle (2011) & $\begin{array}{l}\text { Decreased testicular volume, impaired sperm quality and } \\
\text { decline of Leydig cell secretion }\end{array}$ \\
\hline & $\begin{array}{l}\text { Agarwal et al. (2009), Benoff, Marmar, and } \\
\text { Hurley (2009) }\end{array}$ & Increased ROS and SDF \\
\hline & $\begin{array}{l}\text { Hurtado de Catalfo et al. (2007), Lacerda } \\
\text { et al. (2011) }\end{array}$ & Varicocelectomy decreases ROS and increases TAC \\
\hline \multirow[t]{3}{*}{ Advanced Male Age } & Gao et al. (2007), Sobreiro et al. (2005) & $\begin{array}{l}\text { Negative impact on semen volume, sperm motility, normal } \\
\text { morphology }\end{array}$ \\
\hline & Alshahrani et al. (2014) & Increased risk of abortion and genetic diseases \\
\hline & Alshahrani, et al., 2014) Colasante et al. (2019) & Increased SDF in men aged $>40$ years \\
\hline \multirow[t]{2}{*}{$\begin{array}{l}\text { Heat Exposure and Scrotal } \\
\text { Hyperthermia }\end{array}$} & $\begin{array}{l}\text { Lavranos et al. (2012), Jung et al. (2008); Jung } \\
\text { and Schuppe (2007); Garolla et al. (2013) }\end{array}$ & Decreased motility \\
\hline & $\begin{array}{l}\text { Lavranos et al. (2012); Rao et al. (2015), } \\
\text { Shiraishi et al. (2010) }\end{array}$ & Increased oxidative stress \\
\hline \multirow[t]{3}{*}{ Genital Tract Infections } & Pasqualotto et al. (2000) & Correlation between chronic prostatitis and ROS \\
\hline & Lobascio et al. (2015) & Increased ROS and SDF (TUNEL) \\
\hline & Vicari (2000) & Antibiotic treatment might help to decrease ROS production \\
\hline \multirow[t]{2}{*}{ Obesity } & Kort et al. (2006), Campbell et al. (2015) & Increased SDF \\
\hline & Dupont et al. (2013) & Lower sperm motility and increased SDF. \\
\hline \multirow[t]{4}{*}{ Diabetes mellitus (DM) } & Amaral et al. (2008) & $\begin{array}{l}\text { Decreased sperm motility and normal morphology } \\
\text { Increased ROS production }\end{array}$ \\
\hline & Agbaje et al. (2007) & Sperm nuclear and mtDNA damages \\
\hline & Pourmasumi et al. (2017) & Higher $80 \mathrm{HdG}$ levels in men with DM \\
\hline & Condorelli et al. (2018) & $\begin{array}{l}\text { Higher percentage of SDF and apoptosis markers men with } \\
\text { DM2 }\end{array}$ \\
\hline \multirow[t]{3}{*}{ Cancer } & Pourmasumi et al. (2017) & $\begin{array}{l}\text { Cancer progression may induce increase in sperm DNA } \\
\text { damage }\end{array}$ \\
\hline & $\begin{array}{l}\text { O'Flaherty et al. (2008), Kumar et al. (2018), } \\
\text { Marchlewska et al. (2016) }\end{array}$ & Increased SDF in patients with testicular cancer \\
\hline & O'Flaherty et al. (2008) & Increased SDF in patients with Hodgkin's disease \\
\hline
\end{tabular}

cause of male infertility (Agarwal et al., 2009). Varicocele is associated with decreased testicular volume, impaired sperm quality and a decline of Leydig cell function (WHO, 1992). Emerging evidence has demonstrated a link between increased seminal ROS and sperm DNA damage in varicocele patients (Abdelbaki, Sabry, Al-Adl, \& Sabry, 2017; Naelitz \& Parekh, 2019). This associated rise in ROS is partly attributed to testicular hypoxia, elevated testicular and scrotal temperature, reflux of metabolites and cadmium accumulation. The excessive ROS generation has been correlated with increased SDF in varicocele patients (Esteves \& Agarwal, 2016). Therefore, both ROS and SDF are involved in the pathophysiology of varicocele-mediated male infertility (Figure 1; Cho, Esteves, \& Agarwal, 2016).

Although the mechanisms associated with oxidative stress in varicocele are still unclear, the main factors responsible for ROS generation are related to scrotal hyperthermia, testicular hypoxia, reflux of adrenal/renal metabolites and cadmium accumulation (Roque \& Esteves, 2018; Figure 1). Pro-inflammatory cytokines interferon-gamma (INF ${ }_{\gamma}$ ), tumour necrosis factor-alpha (TNF $\alpha$ ), interleukin (IL)- 1 and IL- 6 increase production of ROS in varicocele, inducing DNA damage. Furthermore, the pro-inflammatory adipokine leptin may be involved in the pathogenesis of reproductive dysfunction in varicocele and the associated increased ROS production (Habibi, Seifi, Mougahi, Ojaghi, \& Sadeghipour, 2015; Wang et al., 2015). Through inactivation of voltage-dependent calcium channels that lack the ion selection property due to deletion of an exon in the $\alpha_{1 c}$ subunit, cadmium can pass through these defective channels and enter seminiferous epithelial cells. In turn, increased levels of cadmium can result in elevated ROS and decreased antioxidant capacity (Agarwal et al., 2009). In addition, an increased HO-isoenzyme 1 expression may stimulate apoptosis, increase the carbon monoxide level and induce apoptosis of Leydig cells (Agarwal et al., 2009). Importantly, varicocele repair improves oxidative stress in these patients, suggesting that seminal oxidative stress is primarily caused by the varicocele (Hurtado de Catalfo, Ranieri-Casilla, Marra, de Alaniz, \& Marra, 2007; Lacerda et al., 2011) (Lacerda et al., 2011). Therefore, there is a close interconnection in the complex mechanisms associated with SDF in varicocele; however, any cause-effect relationship between varicocele and SDF remains to be proven (Zini \& Dohle, 2011). 


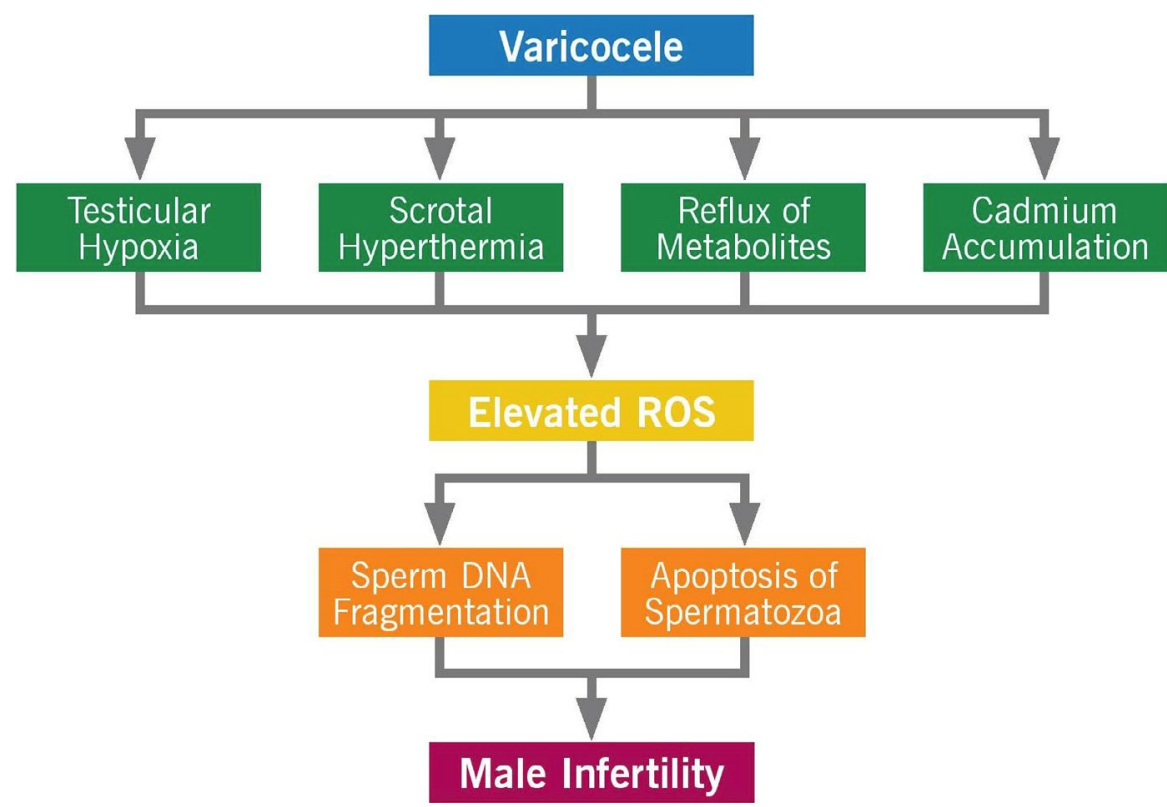

FIGURE 1 Causes of sperm DNA damage in varicocele-mediated male infertility

\subsubsection{Advanced male age}

Over the last few decades, many couples in developed countries are delaying parenthood (Alshahrani et al., 2014). Birth rates for men older than 35 years have increased by $40 \%$ since 1980 in the United States (Kovac et al., 2013). Advanced paternal age has a negative impact on semen volume, sperm motility and morphology (Gao et al., 2007; Sobreiro et al., 2005). This has also been linked to increased risk of abortion and genetic diseases in the offspring (Alshahrani et al., 2014). Similarly, increased sperm DNA damage is also associated with ageing and poor fertility outcomes. Higher rates of SDF were shown in nonazoospermic infertile men $>40$ years compared to their younger counterparts $(p<.05)$, without any difference in semen parameters (Alshahrani et al., 2014). Colasante et al. reported that in a mixed population of fertile and infertile men, higher levels of SDF were observed in patients aged $>41$ years in contrast to younger men $(p<$.009) (Colasante et al., 2019). A recent crosssectional study showed that sperm DNA damage and mitochondrial defects increased significantly with age (Rao et al., 2015). Shiraishi et al. also observed a relationship between temperature and oxidative stress by measuring the expression of 4-HNE-modified proteins in varicocele patients. The findings of the study revealed that an elevation of scrotal temperature is closely associated with increased intratesticular oxidative stress (Shiraishi, Takihara, \& Matsuyama, 2010).

\subsection{3 | Genital Tract Infections}

A common cause of male infertility includes numerous reproductive tract infections. An overproduction of ROS during an infection results in oxidative stress-induced DNA damage. A positive correlation between chronic prostatitis and ROS production has been reported (Agarwal et al., 2018). Chronic prostatitis patients negative for leukocy tospermia have significantly lower total antioxidant capacity (TAC) and patients with leukocytospermia have increased ROS production compared to healthy subjects (Pasqualotto et al., 2000). Seminal leukocytes are able to generate 1,000 times more ROS than spermatozoa (Whittington \& Ford, 2011). A positive correlation between the leucocyte concentration and both total ROS concentration and the number of spermatozoa with DNA fragmentation as determined with the TUNEL assay has been reported (Lobascio et al., 2015). Patients with prostate-vesiculoepididymitis exhibit a significant increase in ROS production when compared to patients with prostatitis alone, demonstrating that the more extensive the infection, the higher the ROS production (La Vignera, Calogero, Cannizzaro, \& Vicari, 2006). In addition, antibiotic treatment for prostatitis can help decrease ROS production, indicating that the presence of bacteria plays an important role in increased levels of ROS (Vicari, 2000). This concept is corroborated by the finding that bacteriospermia is related to high SDF and has a negative effect on semen parameters (Moskovtsev et al., 2010; Pergialiotis, Karampetsou, Perrea, Konstantopoulos, \& Daskalakis, 2018; Vilvanathan et al., 2016). Furthermore, a study regarding urethritis caused by Ureaplasma urealyticum, which is a condition where a large number of leukocytes is not expected, showed increased ROS production (Potts et al., 2000).

\subsection{4 | Obesity}

The prevalence of obesity has notably increased during the last several decades, with $>70 \%$ of adult men classified as overweight or obese in some Western nations (McPherson \& Lane, 2015). Obesity is closely associated with male infertility and increased SDF. This is mediated through disruptions in the hypothalamic-pituitary-gonadal 
axis, resulting in decreased testosterone, and an increase in scrotal temperature due to the excessive adipose tissue in the legs and around the scrotum (Kahn \& Brannigan, 2017). These pathways may lead to impaired spermatogenesis, excessive ROS production and SDF. A meta-analysis on obesity and sperm DNA damage showed that the SDF was significantly increased in obese men compared to men with normal weight (Campbell, Lane, Owens, \& Bakos, 2015). Obesity is also considered a pro-inflammatory state that results in increased systemic inflammation. Intake of high-energy diet containing trans-fatty acids and saturated fats can increase ROS generation and may induce perturbations to epigenetic status (methylation) of sperm affecting the testes and sperm DNA integrity (McPherson \& Lane, 2015; Tsatsanis et al., 2015). Kort et al. reported an increased SDF rate in both overweight and obese men compared to men with normal body mass index (BMI) (Kort et al., 2006). Although SDF is associated with obesity, the mechanisms by which this occurs is complex and remains poorly understood.

\subsection{5 | Diabetes mellitus}

Lower pregnancy rates have been associated with diabetes mellitus (DM). Sperm parameters such as total sperm motility, concentration and abnormal morphology have been reported to be negatively altered in diabetic men (Amaral, Oliveira, \& Ramalho-Santos, 2008). Although the mechanism of reproductive dysfunction remains complex, oxidative stress is implicated in the pathophysiology of DM-associated male infertility (Amaral et al., 2008). With disease progression, the vascular and multi-organ complications in diabetes result in hyperglycemia-induced overproduction of ROS (Amaral et al., 2008). Hormonal factors, such as hyperinsulinemia and hyperleptinemia, alongside pro-inflammatory cytokines, contribute to the generation of oxidative stress and, consequently, SDF (Amaral et al., 2008; Lu, Huang, Zhang, \& Zhao, 2017). DM is associated with increased sperm nuclear and mtDNA damages that may impair the reproductive capability of these men (Agbaje et al., 2007), alongside increased apoptosis signalling, assessed by disrupted transmembrane mitochondrial potential and activated caspase 3 (Roessner, Paasch, Kratzsch, Glander, \& Grunewald, 2012). In addition, 8-OHdG levels are higher in spermatozoa of diabetic patients in comparison with nondiabetic subjects (Pourmasumi et al., 2017). Furthermore, a higher percentage of SDF, ROS and apoptosis markers have been noted in infertile men with diabetes mellitus type 2 (DM2) compared to diabetes mellitus type 1 (DM1) patients and nondiabetic patients, demonstrating that different DM profiles have different effects, which might be related to the importance of insulin resistance in this scenario (Condorelli, La Vignera, Mongioì, Alamo, \& Calogero, 2018).

\subsection{6 | Cancer}

The most common malignancies that affect men of reproductive age are testicular cancer (TC), Hodgkin's disease and leukemia
(Pourmasumi et al., 2017). The progression of cancer can be a predisposing cause of DNA damage and infertility in addition to the negative effects of different types of cancer treatments on male fertility (Pourmasumi et al., 2017). Men with TC and Hodgkin's disease have been found to have increased DNA damage, demonstrated by low degrees of DNA compaction, as assessed by chromomycin A3 (CMA3), and high SDF, as assessed by the Sperm Chromatin Structure Assay (SCSA) and Comet assay (O'Flaherty, Vaisheva, Hales, Chan, \& Robaire, 2008). The chromatin damage in TC patients is reported to be comparable with infertile patients, indicating that TC could be a cause of temporary infertility by inducing sperm DNA damage and thus affecting the semen quality (Paoli, Pallotti, Lenzi, \& Lombardo, 2018).

\section{3 | Extrinsic factors}

The mechanisms involved in sperm DNA damage can be triggered by exogenous factors as well. Exposure to radiation, environmental toxins and tobacco may induce poor lifestyle SDF by different pathways (Cho \& Agarwal, 2018).

\subsection{1 | Radiation}

Testes and spermatogonia are more sensitive to radiation than other types of cells present in the body (Xu et al., 2008). Intensification of fragmentation and total methylation of genomic DNA have been observed in men exposed to radioactive substances (Kumar et al., 2013; Wdowiak, Skrzypek, Stec, \& Panasiuk, 2019). Similar damage to the DNA structure has been observed in spermatozoa of males exposed to nuclear waste (Goncharov et al., 1998). Radiation can be classified into two categories: ionizing and non-ionizing radiation. lonizing radiation is a high-energy radiation, capable of causing thermal and nonthermal (genetic) damage. Male infertility and testicular cancer, where radiation therapy is common, are related to DNA damage (Kesari, Agarwal, \& Henkel, 2018). In cancer patients who have received radiotherapy, a significant but transient increase in SDF occurs in the first 2 years after treatment, but normalised within 3-5 years (Ståhl et al., 2004). Furthermore, patients with testicular cancer treated with radiation have a higher SDF compared to testicular cancer patients who have not received radiotherapy (Smit, van Casteren, Wildhagen, Romijn, \& Dohle, 2010).

Non-ionizing radiation is a low-energy radiation, and the direct biological consequences are attributed to low-energy transfer and thermal action (Angelopoulou, Lavranos, \& Manolakou, 2009; Lavranos, Balla, Tzortzopoulou, Syriou, \& Angelopoulou, 2012). Studies concerning non-ionizing energy are less common due to the difficulty in quantifying the exposure. However, radiation generated by cell phones, $\mathrm{Wi}-\mathrm{Fi}, \mathrm{mi}$ crowaves and laptops has been associated with male infertility (McGill \& Agarwal, 2014). Radiofrequency electromagnetic wave (RF-EMW) radiation emitted from mobile phones affects cells and organelles, and 
disturbs the electron flow in the membranes present inside the cells (Johnson et al., 2007). Furthermore, the activation of NADH oxidase and leukocytes by RF-EMW results in the generation of ROS leading to oxidative stress, which in turn results in radiation-induced SDF (Kesari et al., 2018; Lavranos et al., 2012). Zalata et al. demonstrated a significant decrease in motility and linear velocity and a significant increase in DNA fragmentation in spermatozoa exposed to RF-EMW (Zalata, ElSamanoudy, Shaalan, El-Baiomy, \& Mostafa, 2015).

\subsection{2 | Environmental toxins}

Chemical toxins have a negative impact on sperm structure and function and have become a significant public health concern over the past few decades (Zamkowska, Karwacka, Jurewicz, \& Radwan, 2018). Exposure can be through oral ingestion (food and water), dermal contact, inhalation (dust), intravenously and transfer through the placenta and maternal milk (Zamkowska et al., 2018). Bisphenol A (BPA) is a widespread chemical found in plastics, epoxy resins, and is utilised in the production of many consumer household products and medical devices. Elevated urinary levels of BPA in men are correlated with increased sperm DNA damage and abnormal semen parameters (Meeker et al., 2010; Vitku et al., 2015).

Different types of plastic products also release phthalates, which may also accumulate along the food chain (Zamkowska et al., 2018). A direct correlation has been found between semen phthalate levels and ROS production, and increased DNA fragmentation (Pant et al., 2008). High levels of lead and cadmium can also increase SDF levels (Pant, Kumar, Upadhyay, Gupta, \& Chaturvedi, 2015). Another important toxin, polychlorinated biphenyls (PCB), used in different types of industrial products, is a persistent organochlorine pollutant that is considered a potential endocrine-disrupting compound. Exposure to this toxin has a negative impact on sperm chromatin integrity (Spanò et al., 2005).

Synthetic pyrethroids are frequently found in household and agricultural pesticides (Zamkowska et al., 2018). Pyrethroids are potential endocrine disruptors that can cause reproductive hormonal imbalances, and also induce oxidative stress-mediated sperm DNA damage (Chen et al., 2002; Jurewicz et al., 2015; Meeker, Barr, \& Hauser, 2008). Another toxin, 2,3,7,8-tetrachlorodibenzo-p-dioxin (TCDD), by-product formed during the manufacture of chlorinated hydrocarbons can be accumulated in the food chain (Lavranos et al., 2012) and cause a significant decline in the activities of superoxide dismutase, catalase and glutathione reductase. It also causes increases the levels of hydrogen peroxide and lipid peroxidation in the epididymal spermatozoa, leading to TCDD-induced oxidative stress (Latchoumycandane, Chitra, \& Mathur, 2002). The lipid peroxidation and the oxidative stress induced by exposure to TCDD and ethyleneglycol can cause DNA damage.

\subsection{3 | Smoking}

Approximately $37 \%$ of men of reproductive age smoke cigarettes, with Europe having the highest rates of tobacco use (WHO, 2015).
Cigarettes contain more than 4,000 chemical compounds, and many of them are found in the semen samples of cigarette smokers (Lavranos et al., 2012). Smoking is associated with a $48 \%$ increase in seminal leucocyte concentrations, a $107 \%$ increase in ROS levels and a 10-point decrease in ROS-TAC scores (Saleh et al., 2002). High levels of ROS together with the reduction in antioxidant levels promote oxidative stress-induced DNA damage (Harlev, Agarwal, Gunes, Shetty, \& du Plessis, 2015). Furthermore, the quality of sperm DNA is worse in smokers compared to nonsmokers (Aboulmaouahib et al., 2018; Cui, Jing, Wu, Wang, \& Li, 2016).

Table 2 provides an overview of all the extrinsic causes of sperm DNA damage.

\section{3 | ASSESSMENT OF SPERM DNA FRAGMENTATION}

Different techniques are available to assess SDF. The majority of tests provides information about the single- and/or double-strand breaks in the sperm DNA. The TUNEL assay and SCSA are the most widely used assays (30.6\%) for assessing SDF (Majzoub, Agarwal, Cho, \& Esteves, 2017). However, a recent scientometric analysis revealed TUNEL assay as the most popular test used in the clinical setup (Baskaran et al., 2019) Other SDF tests include sperm chromatin dispersion test (SCD) (20.4\%) and the Comet assay (6.1\%) (Majzoub et al., 2017).

SDF assays are mainly divided into direct and indirect tests. Direct tests measure the degree of DNA damage using probes and dyes, while indirect tests measure the susceptibility of sperm DNA to denaturing conditions (Majzoub, Esteves, Gosalvez, \& Agarwal, 2016). In Table 3, we have categorised the currently available assays into sperm chromatin maturity tests that detect the defects in sperm chromatin structure and SDF tests that measure the damage to the sperm DNA (Table 3). Each technique has been extensively reviewed in previous publications (Cho \& Agarwal, 2018; Elbardisi et al., 2019; Panner Selvam \& Agarwal, 2018).

\section{I CLINICAL IMPLICATIONS OF SDF TESTING}

To date, the incorporation of SDF testing in routine laboratory practice remains controversial. Evidence demonstrates that SDF is associated with male infertility and, more importantly, the effect of sperm DNA damage on clinical outcomes with natural conception or assisted reproduction has been extensively studied in recent years. SDF may affect fertility by hindering fertilization, early embryo development, implantation, pregnancy or time to pregnancy, and miscarriages (Lewis et al., 2013). Despite the recent recognition of the value of DNA fragmentation by the American Urological Association (AUA) and European Association of Urology (EAU) in their current guidelines (Jarow et al., 2011; Jungwirth et al., 2018), the role of SDF testing in clinical practice is still not completely defined. This lack 
TABLE 2 Extrinsic causes of sperm DNA damage

\begin{tabular}{|c|c|c|}
\hline Aetiology & Studies & Main findings \\
\hline \multirow[t]{2}{*}{ Ionizing Radiation } & Kesari et al. (2018), Kumar et al. (2013), Wdowiak et al. (2019) & Sperm DNA fragmentation and methylation \\
\hline & Ståhl et al. (2004), Smit et al. (2010) & Increased SDF 2 years after radiotherapy \\
\hline \multirow[t]{2}{*}{ Nonionizing Radiation } & Lavranos et al. (2012), Kesari et al. (2018) & $\begin{array}{l}\text { Activation of NADH oxidase and leukocytes } \\
\text { results in increased oxidative stress }\end{array}$ \\
\hline & Zalata et al. (2015) & Increased SDF. Decreased sperm motility \\
\hline \multirow[t]{12}{*}{ Environmental Toxins } & Bisphenol A & Increased sperm DNA damage and abnormal \\
\hline & Meeker et al. (2010) & semen parameters \\
\hline & Vitku et al. (2015) & \\
\hline & Phthalate & Increased levels of ROS and DNA \\
\hline & Hauser et al. (2007) & fragmentation \\
\hline & Lead and cadmium & Increased SDF \\
\hline & Pant et al. (2015) & \\
\hline & Pyrethroids & Oxidative stress mediated sperm DNA damage \\
\hline & Jurewicz et al. (2015) & \\
\hline & Meeker et al. (2008) & \\
\hline & Polychlorinated biphenyls & Negative impact on sperm chromatin integrity \\
\hline & Spanò et al. (2005) & \\
\hline \multirow[t]{4}{*}{ Smoking } & Saleh et al. (2002) & Increased leucocyte concentrations \\
\hline & Harlev et al. (2015) & Increased ROS \\
\hline & Saleh et al. (2002) & \\
\hline & Aboulmaouahib et al. (2018), Harlev et al. (2015) & Increased DNA damage \\
\hline
\end{tabular}

of clinical rationale has triggered recent publications recommending SDF testing in specific conditions related to varicocele, unexplained infertility, recurrent pregnancy loss and lifestyle risk factors (Agarwal et al., 2016).

\section{1 | Varicocele}

Varicocele is prevalent in $25.4 \%$ of men with abnormal semen parameters and in $11.7 \%$ of men with normal semen analysis (WHO, 1992). Hence, selecting patients who require varicocele repair is important. In the past few decades, the role of SDF in pathophysiology of varicocele has been well documented. Both meta-analyses and systematic reviews have demonstrated high rates of SDF in men with varicocele (Zini \& Dohle, 2011) (Wang, Zhang, Lin, Zhang, \& Zhang, 2012). Varicocelectomy has a beneficial effect with a 78\%-90\% reduction of DNA fragmentation (Moskovtsev et al., 2009; Roque \& Esteves, 2018; Werthman, Wixon, Kasperson, \& Evenson, 2008). A meta-analysis reported that varicocele treatment could improve sperm DNA integrity significantly, with a mean difference of $-3.37 \%$ (95\% Cl -4.09 to $-2.65 ; p<.00001$ ) (Wang et al., 2012). Post-varicocelectomy patients that have lower SDF levels have higher pregnancy rates (Smit et al., 2013) independent of post-surgical sperm count ( $\mathrm{Ni}$ et al., 2016).

Clinical indications of SDF testing remain unclear despite of the large number of clinical studies on sperm DNA integrity. In case of infertile men with clinical varicocele having abnormal semen parameters, major professional societies such as the American Urological Association (AUA) and American Society for Reproductive Medicine
(ASRM) recommend varicocelectomy (Roque \& Esteves, 2018). As discussed earlier, conventional semen analysis cannot distinguish between patients with varicocele and without varicocele who are unable to establish pregnancy. On this basis, the clinical guidelines issued by the 'Society for Translational Medicine' recommend SDF testing should be performed in men with Grade 2 and Grade 3 varicocele and in Grade 1 varicocele having normal and borderline/abnormal semen parameters, respectively (Agarwal, Cho, Majzoub, \& Esteves, 2017), as per WHO 2010. It is noteworthy that this guideline was developed based on the available evidence, which has limited strength. At this point, while adequate evidence is lacking, this guideline allows a more comprehensive evaluation and management of varicocele patients.

\section{2 | Unexplained male infertility}

Conventional semen analysis is unable to identify the etiology in approximately $15 \%$ of men, and they are classified as unexplained male infertility (UMI; Hamada, Esteves, Nizza, \& Agarwal, 2012). About $20 \%$ of men in couples diagnosed as 'unexplained infertile' have DNA fragmentation index (DFI) level $\geq 20 \%$ (Oleszczuk, Augustinsson, Bayat, Giwercman, \& Bungum, 2013; Saleh et al., 2002). This threshold has been associated with decreased fertility in vivo (Spanò et al., 2000). The SDF index can predict the outcome of natural pregnancy, which makes it an additional diagnostic tool in the evaluation of male infertility. A meta-analysis involving 616 couples demonstrated failure of natural pregnancy is directly associated with high SDF with an odds ratio (OR) of 7.01 (Zini, 2011). Hence, SDF testing 


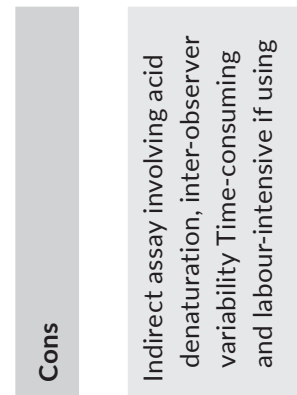

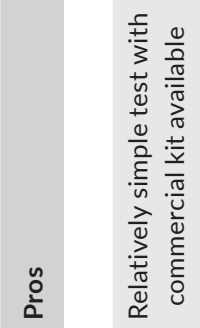

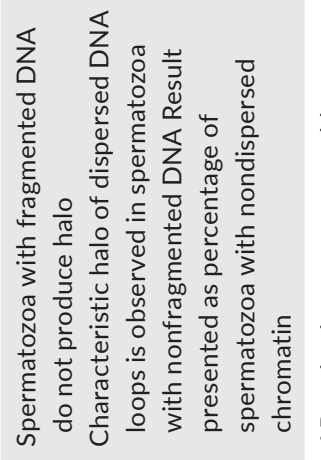

衰
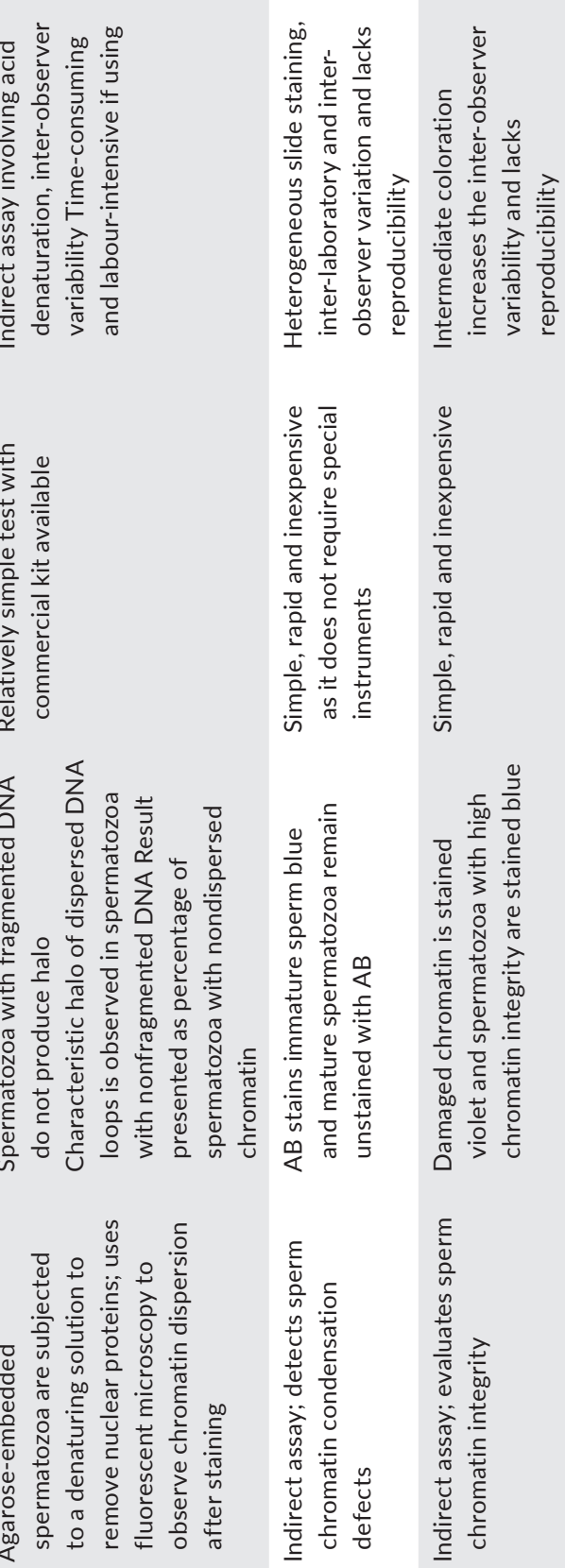
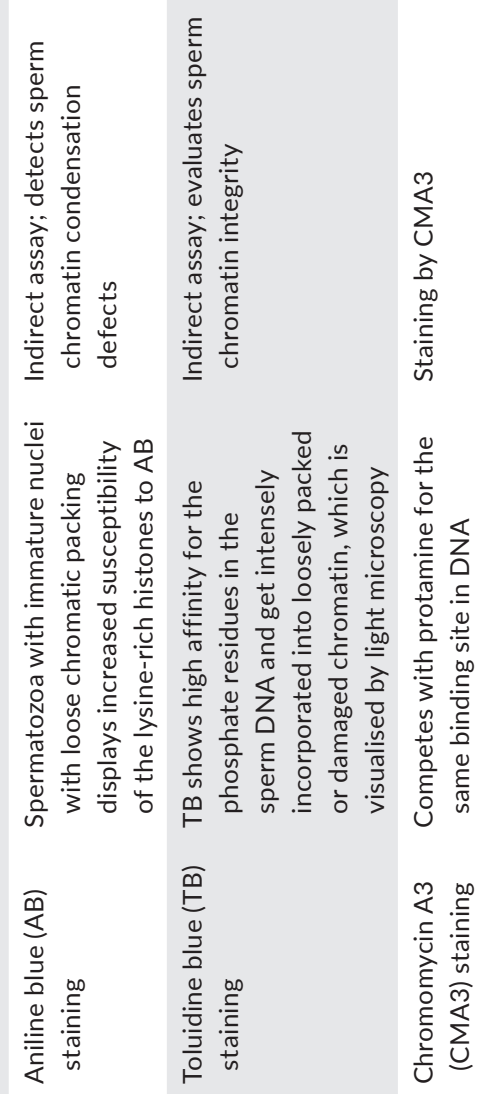
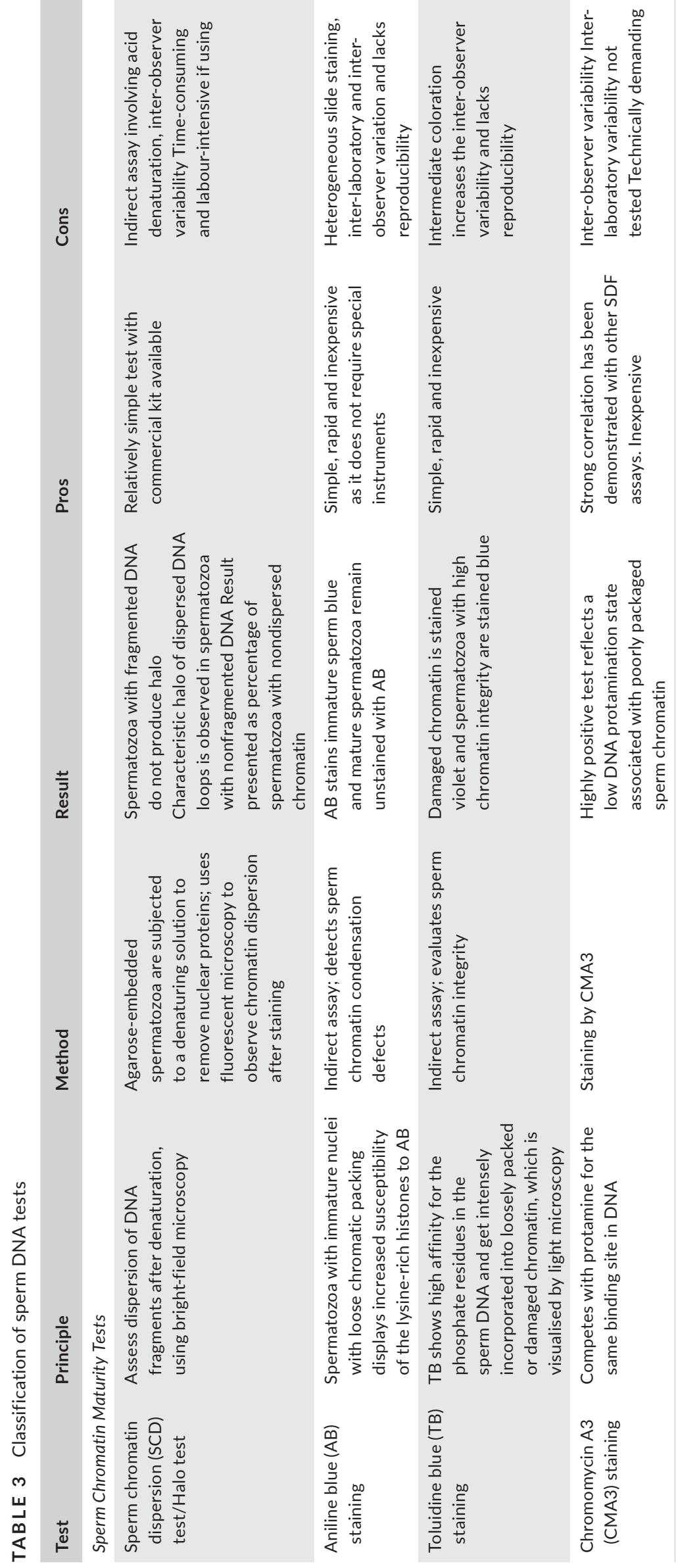
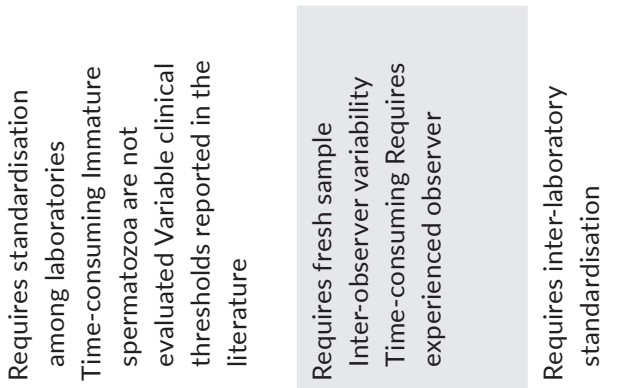

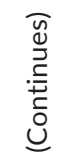
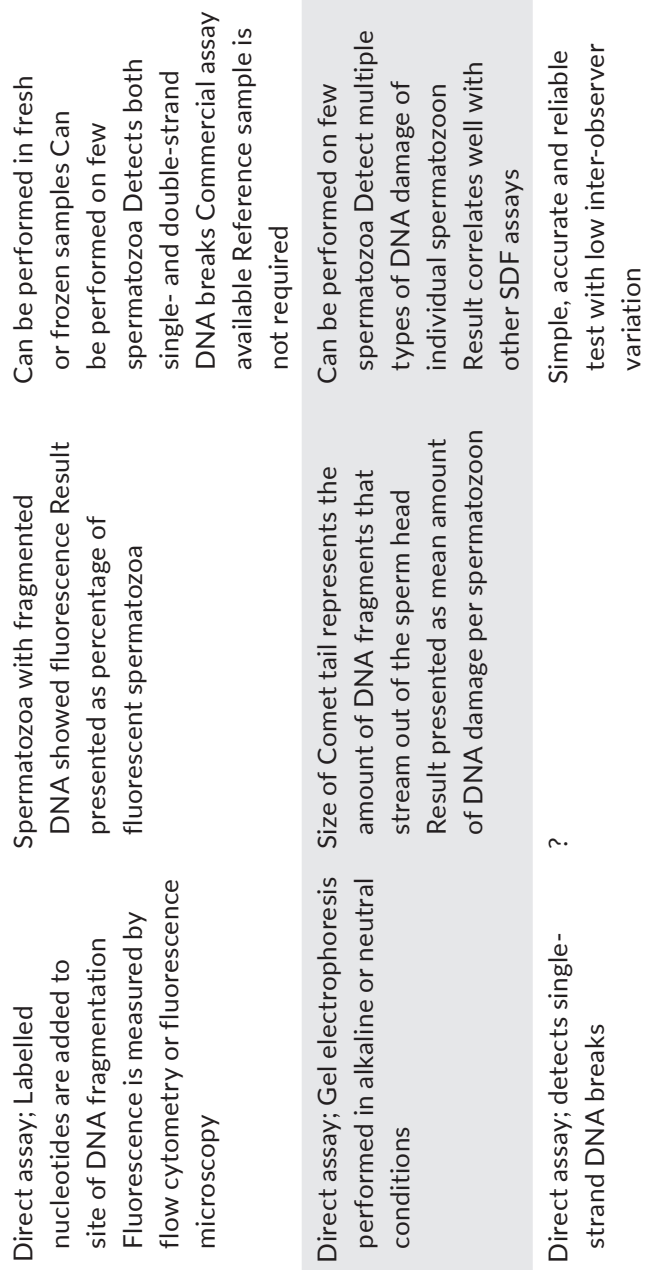

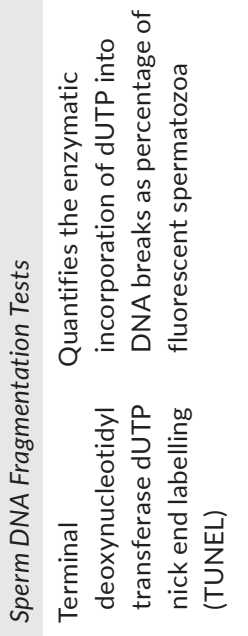

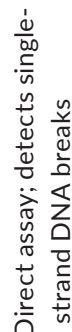
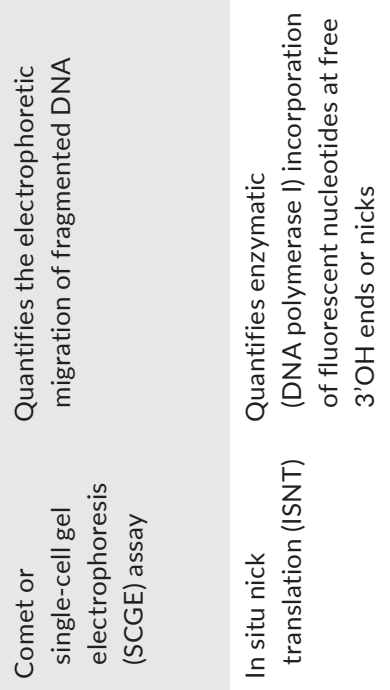

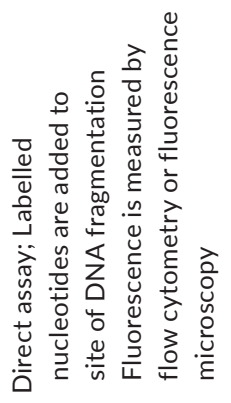




\begin{tabular}{|c|c|c|c|}
\hline రั & 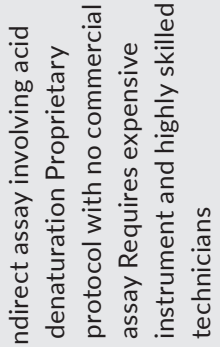 & 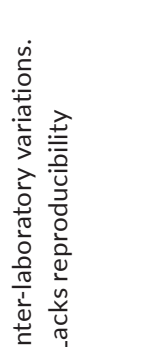 & 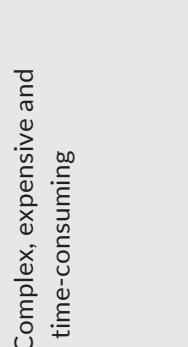 \\
\hline$\stackrel{\text { on }}{0}$ & 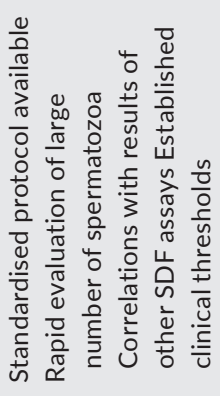 & 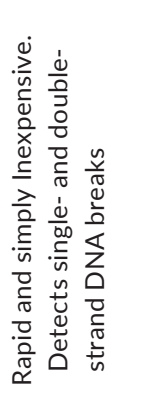 & 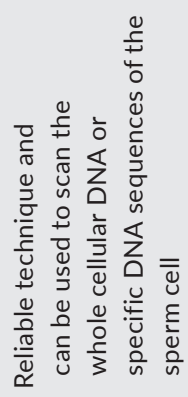 \\
\hline $\begin{array}{l}\frac{\hbar}{\vec{J}} \\
\stackrel{y}{\simeq}\end{array}$ & 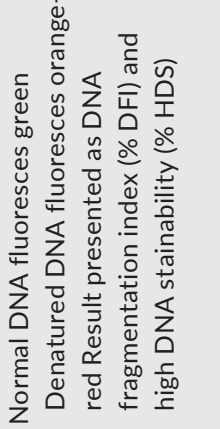 & 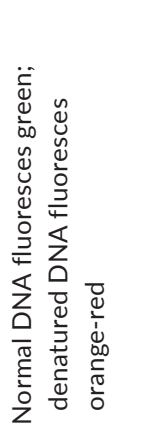 & 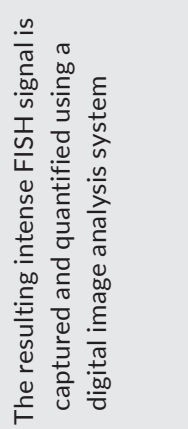 \\
\hline 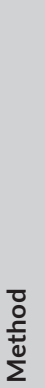 & 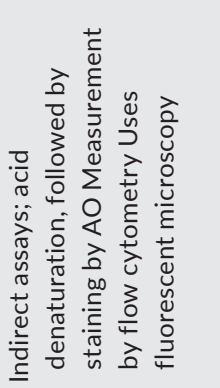 & 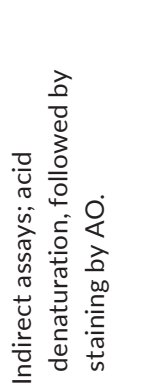 & 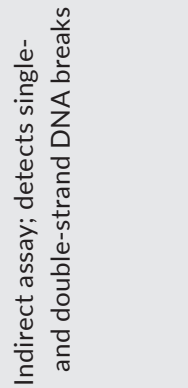 \\
\hline$\frac{\frac{0}{0}}{\frac{0}{\frac{0}{2}}}$ & 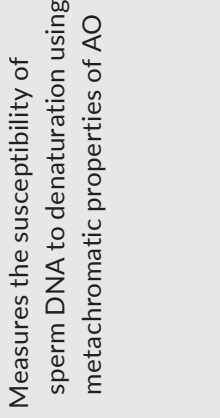 & 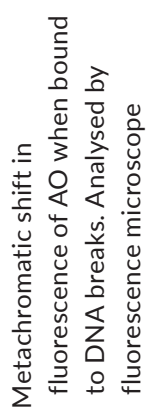 & 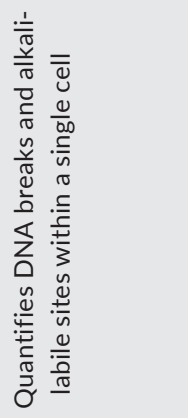 \\
\hline$\stackrel{y}{b}$ & 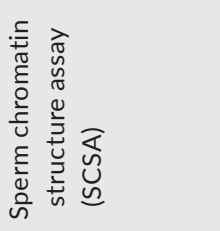 & 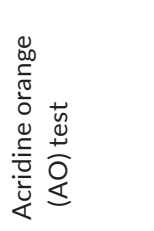 & 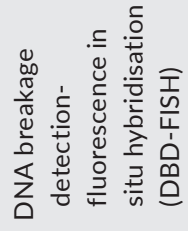 \\
\hline
\end{tabular}

can be recommended for couples with unexplained infertility to investigate a possible underlying aetiology (Cho \& Agarwal, 2018).

\section{3 | Sperm DNA integrity and ART outcomes}

\subsection{1 | Intrauterine insemination}

Intrauterine insemination (IUI) is the first line of treatment in couples who are unable to achieve pregnancy naturally and with no severe male factor on initial investigation (Muriel \& Parekh, 2006). Despite the mild, or even absence of sperm abnormalities in such cases, a proportion of couples are still unable to achieve a pregnancy after several IUI attempts. Sperm DNA damage could be one of the factors associated with pregnancy failure. Duran et al. reported a pregnancy rate of $8.4 \%$ per IUI cycle in which the degree of DNA fragmentation in spermatozoa used for successful IUI was significantly less. Further, no pregnancy was achieved after insemination with samples containing SDF >12\% (Duran, Morshedi, Taylor, \& Oehninger, 2002). Additionally, SDF was also identified as an independent predictor of successful pregnancy in couples undergoing IUI and a DFI $>30 \%$ was determined as the cut-off for higher rates of spontaneous abortions (Rilcheva, Ayvazova, Ilieva, Ivanova, \& Konova, 2016). Bungum et al. confirmed that a SDF cut-off of $>30 \%$, assessed by SCSA, was related to lower pregnancy and delivery rates in patients who underwent IUI (Bungum et al., 2007). A recent meta-analysis based on the outcomes from 1,135 IUI cycles showed a strong association between SDF and IUI outcome (Simon, Emery, \& Carrell, 2019). Based on the above evidences, SDF testing in cases of IUI failure seems to be a reasonable indication. Furthermore, SDF levels can potentially be used as a prognostic factor for IUI outcomes. In such cases, SDF test results prior to the IUI initiation may help to decide whether (in vitro fertilization) IVF should be recommended in cases of IUI failure or even as an alternative for IUI.

\subsection{2 | IVF and ICSI}

Sperm DNA damage has the potential to differentiate between fertile and infertile men. An increased level of SDF negatively affects embryo development and is correlated with an increased time for the embryo to reach the blastocyst stage and pregnancy rates after intracytoplasmic sperm injection (ICSI) (Wdowiak, Bakalczuk, \& Bakalczuk, 2015). A recent meta-analysis assessed SDF rates using different techniques and demonstrated a negative effect of sperm DNA damage on overall pregnancy rate in both IVF and ICSI (OR = 1.68; 95\% Cl: 1.49-1.89, $p<.0001)$. A strong negative association between sperm DNA damage and clinical pregnancy was also observed, even when IVF and ICSI were analyzed separately. A negative effect of sperm DNA damage on clinical pregnancy rate after ART was demonstrated using different techniques, with TUNEL showing the strongest association. Overall, the results show a significant inverse relationship between SDF and clinical 
TA B LE 4 Clinical indications of sperm DNA fragmentation testing (adapted from Agarwal et al., 2017)

Clinical indications of sperm DNA fragmentation testing

Diagnosis and ART Procedures

Varicocele

Unexplained Male Infertility/

Recurrent pregnancy loss with no female factor

IUI

IVF/ICSI

\section{SDF testing applicability}

Better selection of patients to be treated:

Grades 2 and 3 varicocele with normal semen parameters.

Grade 1 varicocele with borderline/ abnormal semen parameters.

SDF testing may clarify aetiology

SDF is a prognostic factor. May help with clinical decisions

Better understanding of failed cycles. Help with clinical decisions pregnancy for IVF and ICSI when TUNEL is used. The other methods did not achieve statistical significance in all scenarios (Simon, Zini, Dyachenko, Ciampi, \& Carrell, 2017).

Osman et al. conducted a meta-analysis and reported a significantly higher live birth rate in men with low SDF after IVF compared to those with high SDF. For men undergoing ICSI, only a slightly significant relationship was observed (Osman, Alsomait, Seshadri, El-Toukhy, \& Khalaf, 2015). The implications of sperm DNA damage on ART outcomes are still a topic of ongoing debate. There is increasing evidence that sperm DNA damage testing can provide outcomes data for clinicians counselling a couple in choosing the best ART method to achieve a pregnancy. Therefore, SDF testing results can be useful in recommending ICSI for couples who have already failed an IVF cycle. In cases, where the failure is due to high SDF, use of testicular spermatozoa with higher levels of DNA integrity can be an alternative.

\subsection{3 | Recurrent pregnancy loss}

Many systematic reviews and meta-analyses have confirmed the association between high SDF and an increased risk of miscarriage after ART (Cho \& Agarwal, 2018; Robinson et al., 2012; Zhao, Zhang, Wang, \& Li, 2014). Zhao et al. observed that high sperm DNA damage was related to higher miscarriage rates in both IVF and ICSI cycles (Zhao et al., 2014). Similarly, a significant increase in miscarriage rates in patients with high SDF compared to those with low SDF with spontaneous and ART pregnancies (Robinson et al., 2012).

The exact definition of recurrent pregnancy loss (RPL) is unclear. It can be considered as two or more failed clinical pregnancies documented by ultrasonographic or histopathologic examination (Medicine, 2012), or as three or more consecutive pregnancy losses without IUI (Jauniaux, Farquharson, Christiansen, \& Exalto, 2006). Nearly, $40 \%-50 \%$ of the RPL cases may be attributed to a male factor; however, female factors remain the most well-defined and thoroughly studied etiologies for RPL (Tan, Taskin, Albert, \& Bedaiwy, 2019). A recent meta-analysis demonstrated a clear association between RPL and high SDF, measured by TUNEL and SCD. Each test was separately analyzed, and the results were validated for both (Tan et al., 2019). Sperm DNA damage testing in cases of pregnancy loss can shed light on the cause(s) of RPL and miscarriage in cases of spontaneous or ART pregnancies.

\subsection{Relevance to clinical practice}

Over the past decade, male factor infertility is considered as one of the major causes of subfertility among couples seeking treatment with IVF (Wilkes, 2013) and conventional semen analysis is not enough to provide complete guidance for clinical practice. Sperm DNA damage involves various abnormalities including DNA fragmentation, DNA cross-linking, abnormal protamination and chromatin compaction (Osman et al., 2015). Recent evidence recommends sperm DNA damage testing as an extra tool that can help understand the pathways of male infertility, as well as managing cases of infertile couples. For this purpose, it is crucial to define the formal indications of DNA damage testing, notably in cases of varicocele, idiopathic male infertility, recurrent pregnancy loss and ART (Table 4).

\section{5 | CONCLUSION}

Sperm DNA damage testing is considered as one of the specialized sperm function assay used to determine the quality of the paternal genome. Sperm DNA integrity is essential for successful natural and assisted conception. It is important to understand the etiologies associated with sperm DNA damage and correlate it with various male infertility scenarios.

Therefore, mitigating the factors inducing sperm DNA damage can be used as one of the main management option for male infertility. Furthermore, sperm DNA testing will help in optimizing the treatment options for couples undergoing ART procedures.

\section{6 | KEY POINTS}

- Sperm DNA damage is one of the major causes of male infertility

- Types of sperm DNA damage include DNA fragmentation, mitochondrial DNA damage, telomere attrition, Y-chromosome microdeletions and epigenetic abnormalities 


\section{7 | POTENTIAL AREAS OF RESEARCH}

- Development of universal cut-off value for the SDF assays is warranted.

- Diagnostic and prognostic value of the available sperm DNA tests must be clearly defined.

\section{ORCID}

Rafael F. Ambar iD https://orcid.org/0000-0002-3496-2895

Ashok Agarwal iD https://orcid.org/0000-0003-0585-1026

Ralf Henkel iD https://orcid.org/0000-0003-1128-2982

Manesh Kumar Panner Selvam iD https://orcid.

org/0000-0002-9120-2278

\section{REFERENCES}

Abdelbaki, S. A., Sabry, J. H., Al-Adl, A. M., \& Sabry, H. H. (2017). The impact of coexisting sperm DNA fragmentation and seminal oxidative stress on the outcome of varicocelectomy in infertile patients: A prospective controlled study. Arab Journal of Urology, 15(2), 131-139.

Aboulmaouahib, S., Madkour, A., Kaarouch, I., Sefrioui, O., Saadani, B., Copin, H., ... Cadi, R. (2018). Impact of alcohol and cigarette smoking consumption in male fertility potential: Looks at lipid peroxidation, enzymatic antioxidant activities and sperm DNA damage. Andrologia, 50(3), e12926. https://doi.org/10.1111/and.12926

Agarwal, A., Cho, C. L., Majzoub, A., \& Esteves, S. C. (2017). The Society for Translational Medicine: Clinical practice guidelines for sperm DNA fragmentation testing in male infertility. Translational Andrology and Urology, 6(Suppl 4), S720-S733.

Agarwal, A., Majzoub, A., Esteves, S. C., Ko, E., Ramasamy, R., \& Zini, A. (2016). Clinical utility of sperm DNA fragmentation testing: Practice recommendations based on clinical scenarios. Translational Andrology and Urology, 5(6), 935-950.

Agarwal, A., Parekh, N., Panner Selvam, M. K., Henkel, R., Shah, R., Homa, S. T., ... Harlev, A. (2019). Male Oxidative Stress Infertility (MOSI): Proposed terminology and clinical practice guidelines for management of idiopathic male infertility. The World Journal of Men's Health, 37(3), 296-312.

Agarwal, A., Rana, M., Qiu, E., AlBunni, H., Bui, A. D., \& Henkel, R. (2018). Role of oxidative stress, infection and inflammation in male infertility. Andrologia, 50(11), e13126.https://doi.org/10.1111/and.13126

Agarwal, A., Sharma, R. K., Desai, N. R., Prabakaran, S., Tavares, A., \& Sabanegh, E. (2009). Role of oxidative stress in pathogenesis of varicocele and infertility. Urology, 73(3), 461-469.

Agbaje, I. M., Rogers, D. A., McVicar, C. M., McClure, N., Atkinson, A. B., Mallidis, C., \& Lewis, S. E. (2007). Insulin dependant diabetes mellitus: Implications for male reproductive function. Human Reproduction, 22(7), 1871-1877.

Ajduk, A., Yamauchi, Y., \& Ward, M. A. (2006). Sperm chromatin remodeling after intracytoplasmic sperm injection differs from that of in vitro fertilization. Biology of Reproduction, 75(3), 442-451.

Alsaikhan, B., Alrabeeah, K., Delouya, G., \& Zini, A. (2016). Epidemiology of varicocele. Asian Journal of Andrology, 18(2), 179-181.

Alshahrani, S., Agarwal, A., Assidi, M., Abuzenadah, A. M., Durairajanayagam, D., Ayaz, A., ... Sabanegh, E. (2014). Infertile men older than 40 years are at higher risk of sperm DNA damage. Reproductive Biology and Endocrinology, 12, 103.https://doi. org/10.1186/1477-7827-12-103

Amaral, S., Oliveira, P. J., \& Ramalho-Santos, J. (2008). Diabetes and the impairment of reproductive function: Possible role of mitochondria and reactive oxygen species. Current Diabetes Review, 4(1), 46-54.

Angelopoulou, R., Lavranos, G., \& Manolakou, P. (2009). ROS in the aging male: Model diseases with ROS-related pathophysiology.
Reproductive Toxicology, 28(2), 167-171. https://doi.org/10.1016/j. reprotox.2009.04.003

Baskaran, S., Agarwal, A., Panner Selvam, M. K., Finelli, R., Robert, K. A., lovine, C., ... Henkel, R. (2019). Tracking research trends and hotspots in sperm DNA fragmentation testing for the evaluation of male infertility: A scientometric analysis. Reproductive Biology and Endocrinology, 17(1), 110.https://doi.org/10.1186/s12958-019-0550-3

Benoff, S., Marmar, J. L., \& Hurley, I. R. (2009). Molecular and other predictors for infertility in patients with varicoceles. Frontiers in Bioscience (Landmark Ed), 14, 3641-3672.

Braude, P., Bolton, V., \& Moore, S. (1988). Human gene expression first occurs between the four- and eight-cell stages of preimplantation development. Nature, 332(6163), 459-461.

Bui, A. D., Sharma, R., Henkel, R., \& Agarwal, A. (2018). Reactive oxygen species impact on sperm DNA and its role in male infertility. Andrologia, 50(8), e13012.https://doi.org/10.1111/and.13012

Bungum, M., Humaidan, P., Axmon, A., Spano, M., Bungum, L., Erenpreiss, J., \& Giwercman, A. (2007). Sperm DNA integrity assessment in prediction of assisted reproduction technology outcome. Human Reproduction, 22(1), 174-179.

Campbell, J. M., Lane, M., Owens, J. A., \& Bakos, H. W. (2015). Paternal obesity negatively affects male fertility and assisted reproduction outcomes: A systematic review and meta-analysis. Reproductive BioMedicine Online, 31(5), 593-604.

Chen, H., Xiao, J., Hu, G., Zhou, J., Xiao, H., \& Wang, X. (2002). Estrogenicity of organophosphorus and pyrethroid pesticides. Journal of Toxicology and Environmental Health, Part A, 65(19), 1419-1435.

Cho, C. L., \& Agarwal, A. (2018). Role of sperm DNA fragmentation in male factor infertility: A systematic review. Arab Journal of Urology, 16(1), 21-34

Cho, C. L., Esteves, S. C., \& Agarwal, A. (2016). Novel insights into the pathophysiology of varicocele and its association with reactive oxygen species and sperm DNA fragmentation. Asian Journal of Andrology, 18(2), 186-193.

Colasante, A., Minasi, M. G., Scarselli, F., Casciani, V., Zazzaro, V., Ruberti, A., ... Greco, E. (2019). The aging male: Relationship between male age, sperm quality and sperm DNA damage in an unselected population of 3124 men attending the fertility centre for the first time. Archivio Italiano Di Urologia, Andrologia, 90(4), 254-259.

Condorelli, R. A., La Vignera, S., Mongioì, L. M., Alamo, A., \& Calogero, A. E. (2018). Diabetes mellitus and infertility: different pathophysiological effects in type 1 and type 2 on sperm function. Frontiers in Endocrinology (Lausanne), 9, 268.https://doi.org/10.3389/ fendo.2018.00268

Conwell, C. C., Vilfan, I. D., \& Hud, N. V. (2003)., Controlling the size of nanoscale toroidal DNA condensates with static curvature and ionic strength. Proceedings of the National Academy of Sciences, 100(16), 9296-9301.

Cui, X., Jing, X., Wu, X., Wang, Z., \& Li, Q. (2016). Potential effect of smoking on semen quality through DNA damage and the downregulation of Chk1 in sperm. Molecular Medicine Reports, 14(1), 753-761.

Dupont, C., Faure, C., Sermondade, N., Boubaya, M., Eustache, F., Clément, P., ... Levy, R. (2013). Obesity leads to higher risk of sperm DNA damage in infertile patients. Asian Journal of Andrology, 15(5), 622-625.

Duran, E. H., Morshedi, M., Taylor, S., \& Oehninger, S. (2002). Sperm DNA quality predicts intrauterine insemination outcome: A prospective cohort study. Human Reproduction, 17(12), 3122-3128. https:// doi.org/10.1093/humrep/17.12.3122

Elbardisi, H., Finelli, R., Agarwal, A., Majzoub, A., Henkel, R., \& Arafa, M. (2019). Predictive value of oxidative stress testing in semen for sperm DNA fragmentation assessed by sperm chromatin dispersion test. Andrology, 8(3), 610-617 
Erenpreiss, J., Bars, J., Lipatnikova, V., Erenpreiss, J., \& Zalkalnas, J. (2001). Comparative study of cytochemical tests for sperm chromatin integrity. Journal of Andrology, 22(1), 45-53.

Erenpreiss, J., Spano, M., Erenpreisa, J., Bungum, M., \& Giwercman, A. (2006). Sperm chromatin structure and male fertility: Biological and clinical aspects. Asian J Androl, 8(1), 11-29.

Esteves, S. C., \& Agarwal, A. (2016). Afterword to varicocele and male infertility: Current concepts and future perspectives. Asian Journal of Andrology, 18(2), 319-322.

Esteves, S. C., Sharma, R. K., Gosálvez, J., \& Agarwal, A. (2014). A translational medicine appraisal of specialized andrology testing in unexplained male infertility. International Urology and Nephrology, 46(6), 1037-1052.

Evenson, D. P., Jost, L. K., Marshall, D., Zinaman, M. J., Clegg, E., Purvis, K., ... Claussen, O. P. (1999). Utility of the sperm chromatin structure assay as a diagnostic and prognostic tool in the human fertility clinic. Human Reproduction, 14(4), 1039-1049.

Gao, J., Gao, E. S., Yang, Q., Walker, M., Wu, J. Q., Zhou, W. J., \& Wen, S. W. (2007). Semen quality in a residential, geographic and age representative sample of healthy Chinese men. Human Reproduction, 22(2), 477-484.

Garolla, A., Torino, M., Sartini, B., Cosci, I., Patassini, C., Carraro, U., \& Foresta, C. (2013). Seminal and molecular evidence that sauna exposure affects human spermatogenesis. Human Reproduction, 28(4), 877-885.

Goncharov, N. P., Katsiya, G. V., Kolesnikova, G. S., Dobracheva, G. A., Todua, T. N., Vax, V. V., ... Waites, G. M. (1998). Endocrine and reproductive health status of men who had experienced short-term radiation exposure at Chernobyl. International Journal of Andrology, 21(5), 271-276.

Griswold, M. D. (1998). The central role of Sertoli cells in spermatogenesis. Seminars in Cell \& Developmental Biology, 9(4), 411-416.

Habibi, B., Seifi, B., Mougahi, S. M., Ojaghi, M., \& Sadeghipour, H. R. (2015). Increases in interleukin-6 and interferon-gamma levels is progressive in immature rats with varicocele. Irish Journal of Medical Science, 184(2), 531-537.

Hamada, A., Esteves, S. C., Nizza, M., \& Agarwal, A. (2012). Unexplained male infertility: Diagnosis and management. International Brazilian Journal of Urology, 38(5), 576-594.

Harlev, A., Agarwal, A., Gunes, S. O., Shetty, A., \& du Plessis, S. S. (2015). Smoking and male infertility: An evidence-based review. The World Journal of Men's Health, 33(3), 143-160. https://doi.org/10.5534/ wjmh.2015.33.3.143

Hauser, R., Meeker, J. D., Singh, N. P., Silva, M. J., Ryan, L., Duty, S., \& Calafat, A. M. (2007). DNA damage in human sperm is related to urinary levels of phthalate monoester and oxidative metabolites. Human Reproduction, 22(3), 688-695.

Henkel, R. R. (2011). Leukocytes and oxidative stress: Dilemma for sperm function and male fertility. Asian Journal of Andrology, 13(1), 43-52.

Huang, C. C., Lin, D. P., Tsao, H. M., Cheng, T. C., Liu, C. H., \& Lee, M. S. (2005). Sperm DNA fragmentation negatively correlates with velocity and fertilization rates but might not affect pregnancy rates. Fertility and Sterility, 84(1), 130-140.

Hurtado de Catalfo, G. E., Ranieri-Casilla, A., Marra, F. A., de Alaniz, M. J., \& Marra, C. A. (2007). Oxidative stress biomarkers and hormonal profile in human patients undergoing varicocelectomy. International Journal of Andrology, 30(6), 519-530.

Jarow, J., Sigman, M., Kolettis, P. N., Lipshultz, L. R., McClure, R. D. Nangia, A. K., ... Schlegel, P. N. (2011). The optimal evaluation of the infertile male: best practice statement. Retrieved from https://www. auanet.org/education/guidelines/maleinfertility-d.cfm

Jauniaux, E., Farquharson, R. G., Christiansen, O. B., \& Exalto, N. (2006). Evidence-based guidelines for the investigation and medical treatment of recurrent miscarriage. Human Reproduction, 21(9), 2216-2222.

Johnson, R. D., Navratil, M., Poe, B. G., Xiong, G., Olson, K. J., Ahmadzadeh, H., ... Arriaga, E. A. (2007). Analysis of mitochondria isolated from single cells. Analytical and Bioanalytical Chemistry, 387(1), 107-118.

Jung, A., \& Schuppe, H. C. (2007). Influence of genital heat stress on semen quality in humans. Andrologia, 39(6), 203-215.

Jung, A., Strauss, P., Lindner, H. J., \& Schuppe, H. C. (2008). Influence of heating car seats on scrotal temperature. Fertil Steril., 90(2), 335-339.

Jungwirth, A., Diemer, T., Kopa, Z., Krausz, C., Minhas, S., \& Tournaye, H. (2018). EAU Guidelines on Male Infertility - EAU Guidelines. Edn. Presented at the EAU Annual Congress Copenhagen 2018. Retrieved from http://uroweb.org/guidelines/compilations-of-all-guidelines/

Jurewicz, J., Radwan, M., Wielgomas, B., Sobala, W., Piskunowicz, M., Radwan, P., ... Hanke, W. (2015). The effect of environmental exposure to pyrethroids and DNA damage in human sperm. Systems Biology in Reproductive Medicine, 61(1), 37-43.

Kahn, B. E., \& Brannigan, R. E. (2017). Obesity and male infertility. Current Opinion in Urology, 27(5), 441-445.

Kesari, K. K., Agarwal, A., \& Henkel, R. (2018). Radiations and male fertility. Reproductive Biology and Endocrinology, 16(1), 118.https://doi. org/10.1186/s12958-018-0431-1

Kort, H. I., Massey, J. B., Elsner, C. W., Mitchell-Leef, D., Shapiro, D. B., Witt, M. A., \& Roudebush, W. E. (2006). Impact of body mass index values on sperm quantity and quality. Journal of Andrology, 27(3), 450-452.

Kovac, J. R., Addai, J., Smith, R. P., Coward, R. M., Lamb, D. J., \& Lipshultz, L. I. (2013). The effects of advanced paternal age on fertility. Asian Journal of Andrology, 15(6), 723-728.

Kumar, D., Salian, S. R., Kalthur, G., Uppangala, S., Kumari, S., Challapalli, S., ... Adiga, S. K. (2013). Semen abnormalities, sperm DNA damage and global hypermethylation in health workers occupationally exposed to ionizing radiation. PLoS One, 8(7), e69927.https://doi. org/10.1371/journal.pone.0069927

Kumar, K., Lewis, S., Vinci, S., Riera-Escamilla, A., Fino, M. G., Tamburrino, L., ... Krausz, C. (2018). Evaluation of sperm DNA quality in men presenting with testicular cancer and lymphoma using alkaline and neutral Comet assays. Andrology, 6(1), 230-235.

La Vignera, S., Calogero, A. E., Cannizzaro, M. A., \& Vicari, E. (2006). Mono or bilateral inflammatory postmicrobial prostato-vesciculo-epididymitis: Differences in semen parameters and reactive oxygen species production. Minerva Endocrinologica, 31(4), 263-272.

Lacerda, J. I., Del Giudice, P. T., da Silva, B. F., Nichi, M., Fariello, R. M., Fraietta, R., ... Cedenho, A. P. (2011). Adolescent varicocele: Improved sperm function after varicocelectomy. Fertility and Sterility, 95(3), 994-999.

Latchoumycandane, C., Chitra, C., \& Mathur, P. (2002). Induction of oxidative stress in rat epididymal sperm after exposure to 2,3,7,8-tetrachlorodibenzo-p-dioxin. Archives of Toxicology, 76(2), 113-118.

Lavranos, G., Balla, M., Tzortzopoulou, A., Syriou, V., \& Angelopoulou, R. (2012). Investigating ROS sources in male infertility: A common end for numerous pathways. Reproductive Toxicology, 34(3), 298-307.

Lee, J., Richburg, J. H., Younkin, S. C., \& Boekelheide, K. (1997). The Fas system is a key regulator of germ cell apoptosis in the testis. Endocrinology, 138(5), 2081-2088.

Lewis, S. E., John Aitken, R., Conner, S. J., Iuliis, G. D., Evenson, D. P., Henkel, R., ... Gharagozloo, P. (2013). The impact of sperm DNA damage in assisted conception and beyond: Recent advances in diagnosis and treatment. Reproductive BioMedicine Online, 27(4), 325-337.

Lobascio, A. M., De Felici, M., Anibaldi, M., Greco, P., Minasi, M. G., \& Greco, E. (2015). Involvement of seminal leukocytes, reactive oxygen species, and sperm mitochondrial membrane potential in the DNA damage of the human spermatozoa. Andrology, 3(2), 265-270. 
Lu, X., Huang, Y., Zhang, H., \& Zhao, J. (2017). Effect of diabetes mellitus on the quality and cytokine content of human semen. Journal of Reproductive Immunology, 123, 1-2.

Majzoub, A., Agarwal, A., Cho, C. L., \& Esteves, S. C. (2017). Sperm DNA fragmentation testing: A cross sectional survey on current practices of fertility specialists. Translational Andrology and Urology, 6(Suppl 4), S710-s719.

Majzoub, A., Agarwal, A., \& Esteves, S. C. (2019). Clinical utility of sperm DNA damage in male infertility. Panminerva Medica, 61(2), 118-127.

Majzoub, A., Esteves, S. C., Gosalvez, J., \& Agarwal, A. (2016). Specialized sperm function tests in varicocele and the future of Andrology laboratory. Asian Journal of Andrology, 18(2), 205-212.

Marchlewska, K., Filipiak, E., Walczak-Jedrzejowska, R., Oszukowska, E., Sobkiewicz, S., Wojt, M., ... Slowikowska-Hilczer, J. (2016). Sperm DNA fragmentation index and hyaluronan binding ability in men from infertile couples and men with testicular germ cell tumor. BioMed Research International, 2016, 7893961.https://doi. org/10.1155/2016/7893961

Mayorga-Torres, B. J. M., Camargo, M., Cadavid, Á., du Plessis, S. S., \& Cardona Maya, W. D. (2017). Are oxidative stress markers associated with unexplained male infertility? Andrologia, 49(5), e12659. https:// doi.org/10.1111/and.12659

McGill, J. J., \& Agarwal, A. (2014). The impact of cell phone, laptop computer, and microwave oven usage on male fertility, Male Infertility (pp. 161-177). Berlin, Germany: Springer.

McPherson, N. O., \& Lane, M. (2015). Male obesity and subfertility, is it really about increased adiposity? Asian Journal of Andrology, 17(3), 450-458.

Meeker, J. D., Barr, D. B., \& Hauser, R. (2008). Human semen quality and sperm DNA damage in relation to urinary metabolites of pyrethroid insecticides. Human Reproduction, 23(8), 1932-1940.

Meeker, J. D., Ehrlich, S., Toth, T. L., Wright, D. L., Calafat, A. M., Trisini, A. T., ... Hauser, R. (2010). Semen quality and sperm DNA damage in relation to urinary bisphenol $A$ among men from an infertility clinic. Reproductive Toxicology, 30(4), 532-539.

Moskovtsev, S. I., Lecker, I., Mullen, J. B., Jarvi, K., Willis, J., White, J., \& Lo, K. C. (2009). Cause-specific treatment in patients with high sperm DNA damage resulted in significant DNA improvement. Systems Biology in Reproductive Medicine, 55(2), 109-115.

Moskovtsev, S. I., Mullen, J. B., Lecker, I., Jarvi, K., White, J., Roberts, M., \& Lo, K. C. (2010). Frequency and severity of sperm DNA damage in patients with confirmed cases of male infertility of different aetiologies. Reproductive Biomedicine Online, 20(6), 759-763.

Muriel, L., Meseguer, M., Fernández, J. L., Alvarez, J., Remohí, J. Pellicer, A., \& Garrido, N. (2006). Value of the sperm chromatin dispersion test in predicting pregnancy outcome in intrauterine insemination: A blind prospective study. Human Reproduction, 21(3), 738-744.

Naelitz, B., \& Parekh, N. (2019). Effect of varicocele treatment on oxidative stress markers and sperm DNA fragmentation. In S. C. Esteves, C.-L. Cho, A. Majzoub, \& A. Agarwal (Eds.), Varicocele and male infertility: A complete guide (pp. 271-283). Cham, Switzerland: Springer International Publishing.

Ni, K., Steger, K., Yang, H., Wang, H., Hu, K., Zhang, T., \& Chen, B. (2016). A comprehensive investigation of sperm DNA damage and oxidative stress injury in infertile patients with subclinical, normozoospermic, and astheno/oligozoospermic clinical varicocoele. Andrology, 4(5), 816-824.

O'Flaherty, C., Vaisheva, F., Hales, B. F., Chan, P., \& Robaire, B. (2008) Characterization of sperm chromatin quality in testicular cancer and Hodgkin's lymphoma patients prior to chemotherapy. Human Reproduction, 23(5), 1044-1052.

Oleszczuk, K., Augustinsson, L., Bayat, N., Giwercman, A., \& Bungum, M. (2013). Prevalence of high DNA fragmentation index in male partners of unexplained infertile couples. Andrology, 1(3), 357-360.
Osman, A., Alsomait, H., Seshadri, S., El-Toukhy, T., \& Khalaf, Y. (2015). The effect of sperm DNA fragmentation on live birth rate after IVF or ICSI: A systematic review and meta-analysis. Reproductive BioMedicine Online, 30(2), 120-127.

Page, A. W., \& Orr-Weaver, T. L. (1997). Stopping and starting the meiotic cell cycle. Current Opinion in Genetics \& Development, 7(1), 23-31.

Panner Selvam, M. K., \& Agarwal, A. (2018). A systematic review on sperm DNA fragmentation in male factor infertility: Laboratory assessment. Arab J Urol, 16(1), 65-76.

Pant, N., Kumar, G., Upadhyay, A. D., Gupta, Y. K., \& Chaturvedi, P. K. (2015). Correlation between lead and cadmium concentration and semen quality. Andrologia, 47(8), 887-891.

Pant, N., Shukla, M., Kumar Patel, D., Shukla, Y., Mathur, N., Kumar Gupta, Y., \& Saxena, D. K. (2008). Correlation of phthalate exposures with semen quality. Toxicology and Applied Pharmacology, 231(1), 112-116.

Paoli, D., Pallotti, F., Lenzi, A., \& Lombardo, F. (2018). Fatherhood and Sperm DNA Damage in Testicular Cancer Patients. Frontiers in Endocrinology (Lausanne), 9, 506.https://doi.org/10.3389/fendo.2018.00506

Pasqualotto, F. F., Sharma, R. K., Potts, J. M., Nelson, D. R., Thomas, A. J., \& Agarwal, A. (2000). Seminal oxidative stress in patients with chronic prostatitis. Urology, 55(6), 881-885.

Pergialiotis, V., Karampetsou, N., Perrea, D. N., Konstantopoulos, P., \& Daskalakis, G. (2018). The impact of bacteriospermia on semen parameters: A meta-analysis. J Family Reprod Health, 12(2), 73-83.

Potts, J. M., Sharma, R., Pasqualotto, F., Nelson, D., Hall, G., \& Agarwal, A. (2000). Association of ureaplasma urealyticum with abnormal reactive oxygen species levels and absence of leukocytospermia. Journal of Urology, 163(6), 1775-1778.

Pourmasumi, S., Sabeti, P., Rahiminia, T., Mangoli, E., Tabibnejad, N., \& Talebi, A. R. (2017). The etiologies of DNA abnormalities in male infertility: An assessment and review. International Journal of Reproductive BioMedicine (Yazd), 15(6), 331-344.

Practice Committee of the American Society for Reproductive Medicine. (2012). Evaluation and treatment of recurrent pregnancy loss: A committee opinion. Fertility and Sterility, 98(5), 1103-1111.

Print, C. G., \& Loveland, K. L. (2000). Germ cell suicide: New insights into apoptosis during spermatogenesis. BioEssays, 22(5), 423-430. https://doi.org/10.1002/(SICI)1521-1878(200005)22:5<423:AIDBIES4>3.0.CO;2-0

Rao, M., Zhao, X. L., Yang, J., Hu, S. F., Lei, H., Xia, W., \& Zhu, C. H. (2015). Effect of transient scrotal hyperthermia on sperm parameters, seminal plasma biochemical markers, and oxidative stress in men. Asian Journal of Andrology, 17(4), 668-675.

Rilcheva, V. S., Ayvazova, N. P., Ilieva, L. O., Ivanova, S. P., \& Konova, E. I. (2016). Sperm DNA integrity test and assisted reproductive technology (ART) outcome. Journal of Biomedical and Clinical Research, 2016(9), 21-29.

Robinson, L., Gallos, I. D., Conner, S. J., Rajkhowa, M., Miller, D., Lewis, S., ... Coomarasamy, A. (2012). The effect of sperm DNA fragmentation on miscarriage rates: A systematic review and meta-analysis. Human Reproduction, 27(10), 2908-2917.

Rodriguez, I., Ody, C., Araki, K., Garcia, I., \& Vassalli, P. (1997). An early and massive wave of germinal cell apoptosis is required for the development of functional spermatogenesis. EMBO Journal, 16(9), 2262-2270.

Roessner, C., Paasch, U., Kratzsch, J., Glander, H. J., \& Grunewald, S. (2012). Sperm apoptosis signalling in diabetic men. Reproductive BioMedicine Online, 25(3), 292-299.

Roque, M., \& Esteves, S. C. (2018). Effect of varicocele repair on sperm DNA fragmentation: A review. International Urology and Nephrology, 50(4), 583-603.

Sabanegh, E., \& Agarwal, A. (2010). Male Infertility. In Campbell-Walsh Urology.(pp. 616-647). Philadelphia: Elsevier.

Sakkas, D., Mariethoz, E., \& St John, J. C. (1999). Abnormal sperm parameters in humans are indicative of an abortive apoptotic mechanism 
linked to the Fas-mediated pathway. Experimental Cell Research, 251(2), 350-355.

Saleh, R. A., Agarwal, A., Nelson, D. R., Nada, E. A., El-Tonsy, M. H. Alvarez, J. G., ... Sharma, R. K. (2002). Increased sperm nuclear DNA damage in normozoospermic infertile men: A prospective study. Fertility and Sterility, 78(2), 313-318.

Santi, D., Spaggiari, G., \& Simoni, M. (2018). Sperm DNA fragmentation index as a promising predictive tool for male infertility diagnosis and treatment management - meta-analyses. Reproductive BioMedicine Online, 37(3), 315-326.

Shabana, W., Teleb, M., Dawod, T., Elsayed, E., Desoky, E., Shahin, A., ... Sorour, W. (2015). Predictors of improvement in semen parameters after varicocelectomy for male subfertility: A prospective study. Canadian Urological Association Journal, 9(9-10), E579-582.

Sharlip, I. D., Jarow, J. P., Belker, A. M., Lipshultz, L. I., Sigman, M., Thomas, A. J., ... Sadovsky, R. (2002). Best practice policies for male infertility. Fertility and Sterility, 77(5), 873-882.

Shiraishi, K., Takihara, H., \& Matsuyama, H. (2010). Elevated scrotal temperature, but not varicocele grade, reflects testicular oxidative stress-mediated apoptosis. World Journal of Urology, 28(3), 359-364.

Simon, L., Aston, K., Emery, B., Hotaling, J., \& Carrell, D. (2017). Sperm DNA damage output parameters measured by the alkaline comet assay and their importance. Andrologia, 49(2), e12608.

Simon, L., Emery, B., \& Carrell, D. T. (2019). Sperm DNA fragmentation: Consequences for reproduction. Advances in Experimental Medicine and Biology, 1166, 87-105.

Simon, L., Murphy, K., Shamsi, M., Liu, L., Emery, B., Aston, K., ... Carrell, D. (2014). Paternal influence of sperm DNA integrity on early embryonic development. Human Reproduction, 29(11), 2402-2412.

Simon, L., Zini, A., Dyachenko, A., Ciampi, A., \& Carrell, D. T. (2017). A systematic review and meta-analysis to determine the effect of sperm DNA damage on. Asian Journal of Andrology, 19(1), 80-90.

Smit, M., Romijn, J. C., Wildhagen, M. F., Veldhoven, J. L., Weber, R. F., \& Dohle, G. R. (2013). Decreased sperm DNA fragmentation after surgical varicocelectomy is associated with increased pregnancy rate. Journal of Urology, 189(1 Suppl), S146-150.

Smit, M., van Casteren, N. J., Wildhagen, M. F., Romijn, J. C., \& Dohle, G. R. (2010). Sperm DNA integrity in cancer patients before and after cytotoxic treatment. Human Reproduction, 25(8), 1877-1883.

Sobreiro, B. P., Lucon, A. M., Pasqualotto, F. F., Hallak, J., Athayde, K. S., \& Arap, S. (2005). Semen analysis in fertile patients undergoing vasectomy: Reference values and variations according to age, length of sexual abstinence, seasonality, smoking habits and caffeine intake. Sao Paulo Medical Journal, 123(4), 161-166.

Spanò, M., Bonde, J. P., Hjøllund, H. I., Kolstad, H. A., Cordelli, E., \& Leter, G. (2000). Sperm chromatin damage impairs human fertility. The Danish First Pregnancy Planner Study Team. Fertility and Sterility, 73(1), 43-50.

Spanò, M., Toft, G., Hagmar, L., Eleuteri, P., Rescia, M., Rignell-Hydbom, A., ... INUENDO. (2005). Exposure to PCB and p, p'-DDE in European and Inuit populations: Impact on human sperm chromatin integrity. Human Reproduction, 20(12), 3488-3499.

Spira, A. (1986). Epidemiology of human reproduction. Human Reproduction, 1(2), 111-115.

Ståhl, O., Eberhard, J., Jepson, K., Spano, M., Cwikiel, M., Cavallin-Ståhl, E., \& Giwercman, A. (2004). The impact of testicular carcinoma and its treatment on sperm DNA integrity. Cancer, 100(6), 1137-1144.

Tan, J., Taskin, O., Albert, A., \& Bedaiwy, M. A. (2019). Association between sperm DNA fragmentation and idiopathic recurrent pregnancy loss: A systematic review and meta-analysis. Reproductive BioMedicine Online, 38(6), 951-960.

Thonneau, P., Marchand, S., Tallec, A., Ferial, M. L., Ducot, B., Lansac, J., ... Spira, A. (1991). Incidence and main causes of infertility in a resident population $(1,850,000)$ of three French regions (1988-1989). Human Reproduction, 6(6), 811-816.

Tsatsanis, C., Dermitzaki, E., Avgoustinaki, P., Malliaraki, N., Mytaras, V., \& Margioris, A. N. (2015). The impact of adipose tissue-derived factors on the hypothalamic-pituitary-gonadal (HPG) axis. Hormones (Athens), 14(4), 549-562.

Turner, K. A., Rambhatla, A., Schon, S., Agarwal, A., Krawetz, S. A., Dupree, J. M., \& Avidor-Reiss, T. (2020). Male infertility is a women's health issue-research and clinical evaluation of male infertility is needed. Cells, 9(4). https://doi.org/10.3390/cells9040990

Vicari, E. (2000). Effectiveness and limits of antimicrobial treatment on seminal leukocyte concentration and related reactive oxygen species production in patients with male accessory gland infection. Human Reproduction, 15(12), 2536-2544.

Vilvanathan, S., Kandasamy, B., Jayachandran, A. L., Sathiyanarayanan, S., Tanjore Singaravelu, V., Krishnamurthy, V., \& Elangovan, V. (2016). Bacteriospermia and Its Impact on Basic Semen Parameters among Infertile Men. Interdisciplinary Perspectives of Infectious Diseases, 2016, 2614692

Vitku, J., Sosvorova, L., Chlupacova, T., Hampl, R., Hill, M., Sobotka, V., ... Starka, L. (2015). Differences in bisphenol A and estrogen levels in the plasma and seminal plasma of men with different degrees of infertility. Physiological Research, 64(Suppl 2), S303-311.

Wang, H., Lv, Y., Hu, K., Feng, T., Jin, Y., Wang, Y., ... Chen, B. (2015). Seminal plasma leptin and spermatozoon apoptosis in patients with varicocele and leucocytospermia. Andrologia, 47(6), 655-661.

Wang, Y. J., Zhang, R. Q., Lin, Y. J., Zhang, R. G., \& Zhang, W. L. (2012). Relationship between varicocele and sperm DNA damage and the effect of varicocele repair: A meta-analysis. Reproductive BioMedicine Online, 25(3), 307-314.

Ward, W. S. (2010). Function of sperm chromatin structural elements in fertilization and development. Molecular Human Reproduction, 16(1), 30-36.

Wdowiak, A., Bakalczuk, S., \& Bakalczuk, G. (2015). The effect of sperm DNA fragmentation on the dynamics of the embryonic development in intracytoplasmatic sperm injection. Reproductive Biology, 15(2), 94-100.

Wdowiak, A., Skrzypek, M., Stec, M., \& Panasiuk, L. (2019). Effect of ionizing radiation on the male reproductive system. Annals of Agricultural and Environmental Medicine, 26(2), 210-216.

Werthman, P., Wixon, R., Kasperson, K., \& Evenson, D. P. (2008). Significant decrease in sperm deoxyribonucleic acid fragmentation after varicocelectomy. Fertility and Sterility, 90(5), 1800-1804.

WHO. (1992). The influence of varicocele on parameters of fertility in a large group of men presenting to infertility clinics. Fertility and Sterility, 57(6), 1289-1293.

WHO. (2015). Prevalence of Tobacco Use. 2020.

Wilkes, S. (2013). NICE CG156: Fertility update. What it means for general practitioners. Journal of Family Planning and Reproductive Health Care, 39(4), 241-243.

Xu, G., Intano, G. W., McCarrey, J. R., Walter, R. B., McMahan, C. A., $\&$ Walter, C. A. (2008). Recovery of a low mutant frequency after ionizing radiation-induced mutagenesis during spermatogenesis. Mutation Research, 654(2), 150-157.

Zalata, A., El-Samanoudy, A. Z., Shaalan, D., El-Baiomy, Y., \& Mostafa, T. (2015). In vitro effect of cell phone radiation on motility, DNA fragmentation and clusterin gene expression in human sperm. International Journal of Fertility and Sterility, 9(1), 129-136.

Zamkowska, D., Karwacka, A., Jurewicz, J., \& Radwan, M. (2018). Environmental exposure to non-persistent endocrine disrupting chemicals and semen quality: An overview of the current epidemiological evidence. International Journal of Occupational Medicine and Environmental Health, 31(4), 377-414.

Zandieh, Z., Vatannejad, A., Doosti, M., Zabihzadeh, S., Haddadi, M., Bajelan, L., ... Amanpour, S. (2018). Comparing reactive oxygen 
species and DNA fragmentation in semen samples of unexplained infertile and healthy fertile men. Irish Journal of Medical Science, 187(3), 657-662.

Zhao, J., Zhang, Q., Wang, Y., \& Li, Y. (2014). Whether sperm deoxyribonucleic acid fragmentation has an effect on pregnancy and miscarriage after in vitro fertilization/intracytoplasmic sperm injection: A systematic review and meta-analysis. Fertility and Sterility, 102(4), 998-1005.e1008.

Zini, A. (2011). Are sperm chromatin and DNA defects relevant in the clinic? Systems Biology in Reproductive Medicine, 57(1-2), 78-85.

Zini, A., Azhar, R., Baazeem, A., \& Gabriel, M. S. (2011). Effect of microsurgical varicocelectomy on human sperm chromatin and DNA integrity: a prospective trial. Int J Androl., 34(1), 14-19.
Zini, A., \& Dohle, G. (2011). Are varicoceles associated with increased deoxyribonucleic acid fragmentation? Fertility and Sterility, 96(6), 1283-1287.

How to cite this article: Panner Selvam MK, Ambar RF,

Agarwal A, Henkel R. Etiologies of sperm DNA damage and its impact on male infertility. Andrologia. 2021;53:e13706. https:// doi.org/10.1111/and.13706 